\title{
Inhibitory activity of Lactobacillus plantarum ATCC 8014 fermented milk combined with aqueous extract of Moringa oleifera leaves against Streptococcus mutans
}

\author{
ISNAENI ${ }^{*}$ * (D), Agustin MAULIDINA 1 (D), Idha KUSUMAWATí 1 (D), Erni Maduratna SETYAWATIE ${ }^{2}$ \\ 1 Department of Pharmaceutical Chemistry, Faculty of Pharmacy, Airlangga University, Surabaya, Indonesia. \\ 2 Department of Pharmacognosy and Phytochemistry, Faculty of Pharmacy, Airlangga University, Surabaya, \\ Indonesia. \\ 3 Department of Periodontics, Faculty of Dentistry, Airlangga University, Surabaya, Indonesia. \\ * Corresponding Author. E-mail: isna.yudi@gmail.com (I.); Tel. +62-081-331 021303
}

Received: 23 January 2019 / Revised: 15 April 2019 / Accepted: 01 May 2019

\begin{abstract}
The growth inhibitory activity of Lactobacillus plantarum ATCC 8014 (Lp) fermented milk combined with aqueous extract of Moringa oleifera leaves against Streptococcus mutants has been studied. The preparation is potential developed as healthy food due to its nutritional value as well as its beneficial activities. The well agar diffusion method was applied for the antibacterial assay on nutrient agar media and local strain of Streptococcus mutants was used as a bacterial test. This species often causes infectious in the teeth. Effectiveness of the fermented milk and its combination with aqueous extract preparations against the bacterial test were assessed by minimum inhibitory concentration (MIC) for the potency indication. The aqueous extract of Moringa oleifera leaves was prepared as infuse like according to community daily consumption. Concentration of the extract used in the formulation was higher than the MIC. The result showed that the MIC of the aqueous extract of Moringa oleifera leaves and the L. plantarum fermented milk were $20 \%$ and $35 \%$ with growth inhibition zone diameter of $11.70 \pm 0.28 \mathrm{~mm}$ and $12.02 \pm 0.83 \mathrm{~mm}$, respectively. The combination of fermented milk and aqueous extract was prepared in various ratio concentration (1:9, 2:8, 3:7, 4:6, 5:5, $6: 4,7: 3,8: 2$, and 9:1). The optimum ratio of the combination was $2: 8$ with growth inhibition zone diameter of $16.53 \pm$ $0.32 \mathrm{~mm}$ and the MIC value at optimum ratio was $45 \%$ with inhibition zone diameter of $11.90 \pm 0.86 \mathrm{~mm}$.
\end{abstract}

KEYWORDS: Growth inhibitory; aqueous extract; Moringa oleifera; fermented milk; Lactobacillus plantarum.

\section{INTRODUCTION}

Streptococcus mutans is one of the normal florae in the human oral cavity, but it is often the cause of infectious in the teeth, especially if there is environmental change in bacteria, so the population will increase [1]. In the previous studies reported that dental problems can be overcome with probiotics bacteria, the most popular being Lactobacillus plantarum [2,3]. Oldak et al. (2017) reported antibacterial activity of L. plantarum strain isolated from cheeses against pathogenic microorganism [4]. According to WHO (2002), probiotics are living microorganisms that administered in sufficient amount $\left(10^{6}-10^{8} \mathrm{cfu} / \mathrm{mL}\right)$ can provide health benefits to its host [5]. The combination of Lactobacillus plantarum fermented milk with herbs provided antibacterial activity [6]. In this study the growth inhibitory activity of fermented milk Lactobacillus plantarum ATCC 8014 and Moringa oleifera leaves aqueous extract against Streptococcus mutans was investigated.

Moringa oleifera is known as the "miracle tree", due to its multi-active compounds and properties [7]. Aqueous extracts of Moringa oleifera leaves had been reported their saponin, tannin, flavonoid compounds and showed a broad spectrum antibacterial activity [8]. Ethanol extract of Moringa oleifera leaf also exhibited growth inhibition on Escherichia coli and Staphylococcus aureus [9]. It contains the class of flavonol, quercetin, that proven as antibacterial. Optimization of probiotic drinking of Lactobacillus plantarum MTCC 5422 fermented milk with Moringa oleifera leaves juice and Beta vulgaris L. red root showed activities against Gram positive and negative bacteria such as Escherichia coli and Staphylococcus aureus. The use of Moringa oleifera leaves from local plants that are easy to grow throughout the season is very strategic. Due to the value of its useful content for health will add their value when combined with probiotics fermented milk. Synergistic

How to cite this article: : Isnaeni, Agustin M, Idha K, Erni MS. Inhibitory activity of Lactobacillus plantarum ATCC 8014 fermented milk with aqueous combined extract of Moringa oleifera leaves against Streptococcus mutans. J Res Pharm. 2019; 23(4): 701-710. 
work mechanisms, especially as antibacterial are expected to increase the effectiveness of such combination preparations.

In this research, $50 \%$ of Moringa oleifera leaves aqueous extract made as infuse, according to its traditional utilization in the community as a vegetable and the concentration extract was performed higher than the MIC against Streptococcus mutans. Simple well diffusion method observed the MIC of each test sample: the $50 \%$ of Moringa oleifera leaves aqueous extract, Lactobacillus plantarum ATCC 8014 fermented milk and their combination at various compositions. The MIC of each test sample was compared to combined preparations in the ratio that yielded the maximum activity.

\section{RESULTS}

\subsection{Characterization of the Moringa oleifera leaves aqueous extract}

The characterization of the Moringa oleifera leaves aqueous extract (physical performance, $\mathrm{pH}$ and specific gravity) were useful to ensure reproducibility of results and done under the same conditions (Table 1). In this study, there was no stability test of the extract performed. Standardization and stability test of the extract is necessary to find product quality in term of product development purposes.

Table 1. Characterization of aqueous extract of Moringa oleifera leaves.

\begin{tabular}{lcc}
\hline Organoleptic & pH value & Specific gravity value \\
\hline Color: brown & $5.33 \pm 0.01$ & $1.01 \pm 0.00$ \\
Odor: aromatic & \\
Taste: bitter & & \\
\hline
\end{tabular}

The phytochemical results of the aqueous extract showed different contents (tannins and flavonoids) compared to the library data (Table 2). Based on characterization results, Moringa oleifera leaves aqueous extract was brown, distinctive aroma, bitter taste, $\mathrm{pH}$ value of 5.33 and specific gravity value of $1.01 \mathrm{~g} / \mathrm{mL}$ (Table 1). It was found that the aqueous extract had different contents compare to the reference data, but it contained tannins and flavonoids as antimicrobial compounds. These differences can be caused by several factors including varieties, simplicia character, plant age, location or habitat and harvesting season.

Table 2. Phytochemistry analysis of aqueous extract of Moringa oleifera leaves.

\begin{tabular}{lcc}
\hline $\begin{array}{l}\text { Phytochemistry } \\
\text { identifications }\end{array}$ & Results & References \\
\hline Saponin Glycoside & $(-)$ & $(+)$ \\
Tannin & $(+)$ & $(+)$ \\
Glycoside & $(-)$ & $(+)$ \\
Alkaloid & $(-)$ & $(-)$ \\
Flavonoid & $(+)$ & $(+)$ \\
Terpenoid & $(-)$ & $(+)$ \\
\hline
\end{tabular}

\subsection{Characterization of the fermented milk}

The Lactobacillus plantarum fermented milk had total number of probiotic colony of $1.78 \times 10^{11} \pm 2.59 \times$ $10^{11} \mathrm{CFU} / \mathrm{mL}$ calculated by Total Plate Count (TPC) using MRS media after 24 hours incubation (Table 3). This result is suitable to SNI (Indonesia National Standard) for yogurt or probiotic fermented milk requirement $\left(\geq 10^{7} \mathrm{CFU} / \mathrm{mL}\right)$. 
Table 3. Characterization of probiotic fermented milk.

\begin{tabular}{lcccc}
\hline \multicolumn{1}{c}{ Organoleptic } & pH value & $\begin{array}{c}\text { Specific gravity } \\
(\mathbf{g} / \mathbf{m l})\end{array}$ & $\begin{array}{c}\text { Viscosity } \\
(\mathbf{d P a s})\end{array}$ & ALT (cFu/ml) \\
\hline Color: white & $3.88 \pm 0.00$ & $1.03 \pm 0.00$ & $315.15 \pm 0.13$ & $1.78 \times 10^{11} \pm$ \\
Odor: aromatic & & & & $2.59 \times 10^{11}$ \\
Taste: sour & & & & \\
Form: viscous liquid & & & & \\
\hline
\end{tabular}

\subsection{Characterization of combination of the fermented milk and aqueous extract}

Characterization (physical performance, color, odor, taste, $\mathrm{pH}$, specific gravity and viscosity value) of the Lactobacillus plantarum ATCC 8014 fermented milk and Moringa oleifera leaves aqueous extract at 2:8 composition was done to ensure reproducibility results if done under the same conditions.

Table 4. Characterization of aqueous extract and probiotic fermented milk combination (2:8).

\begin{tabular}{lccc}
\hline Organoleptic & pH value & $\begin{array}{c}\text { Specific gravity } \\
(\mathbf{g} / \mathbf{m l})\end{array}$ & $\begin{array}{c}\text { Viscosity } \\
(\mathbf{d P a s})\end{array}$ \\
\hline Color: white & $4.00 \pm 0.00$ & $1.03 \pm 0.00$ & $140.04 \pm 0.00$ \\
Odor: aromatic & & & \\
Taste: sour & & & \\
Form: viscous liquid & & \\
\hline
\end{tabular}

Their characterization included $\mathrm{pH}$ value of $4.00 \pm 0.00$, specific gravity value of $1.03 \pm 0.00 \mathrm{~g} / \mathrm{mL}$ and viscosity value of $140.04 \pm 0.00 \mathrm{dPas}$ (Table 4 ).

\subsection{Determination of MIC}

Determination of growth inhibitory activity of the Moringa oleifera leaves aqueous extract against Streptococcus mutans growth was performed at various concentrations. The MIC profile of the Moringa oleifera leaves aqueous extract showed that the extract at $20 \%$ still inhibit Streptococcus mutans with growth inhibition zone diameter of $11.70 \pm 0.28 \mathrm{~mm}$ (Figure 1).

The MIC determination of L. plantarum probiotic milk against Streptococcus mutans was done at various concentrations. The results showed that Lactobacillus plantarum fermentation milk at 35\% still inhibited the Streptococcus mutans growth with inhibitory zone diameter of $12.02 \pm 0.83 \mathrm{~mm}$ (Figure 2).

Determination of antibacterial activity of the fermented milk combined with Moringa oleifera leaves aqueous extract at various ratios was investigated from the largest zone diameter. The results showed that composition of the fermented milk and the aqueous extract with the largest growth inhibitory zone diameter was 2:8 with value of $16.53 \pm 0.32 \mathrm{~mm}$ (Figure 3 ).

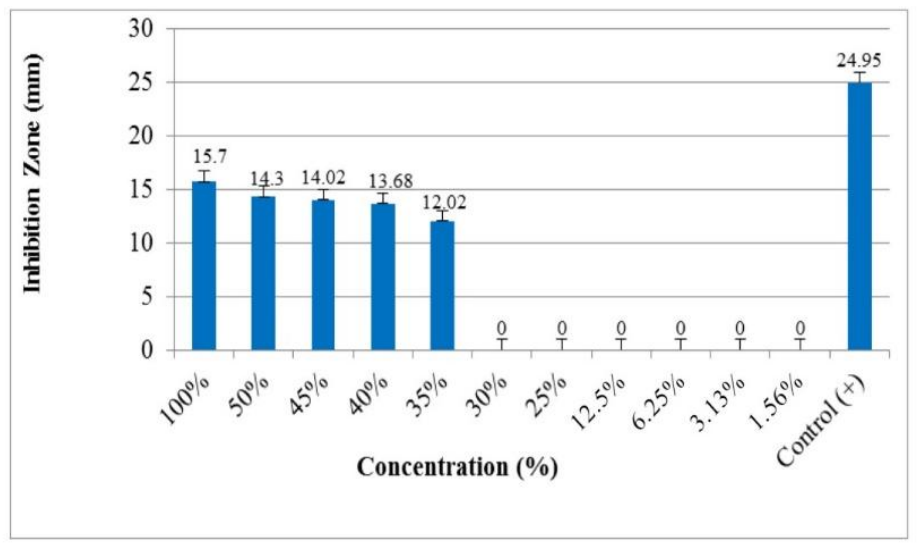

Figure 1. MIC value of aqueous extract of Moringa oleifera leaves. 


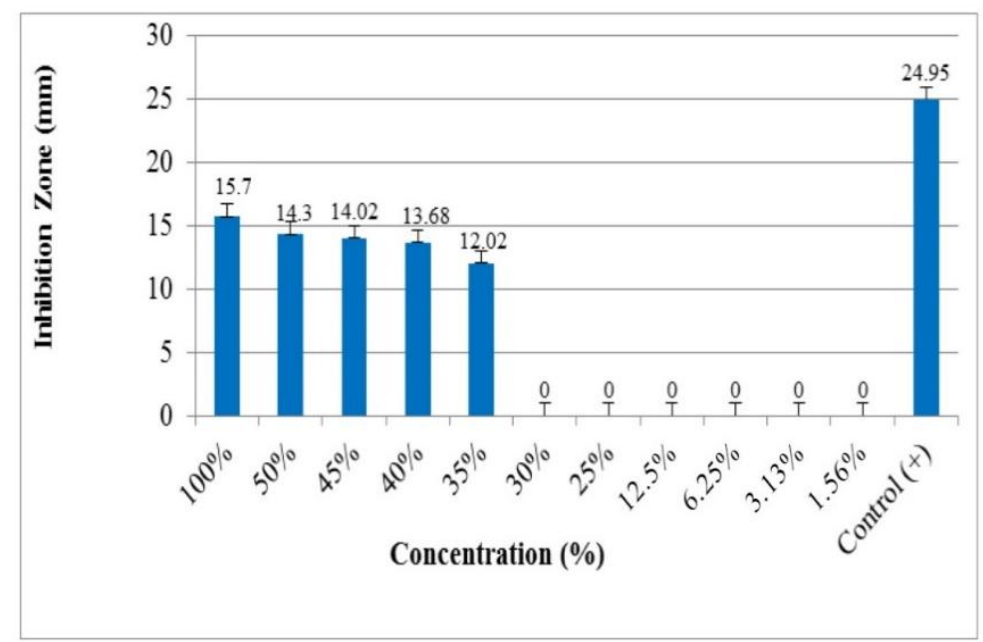

Figure 2. MIC value of probiotic fermented milk.

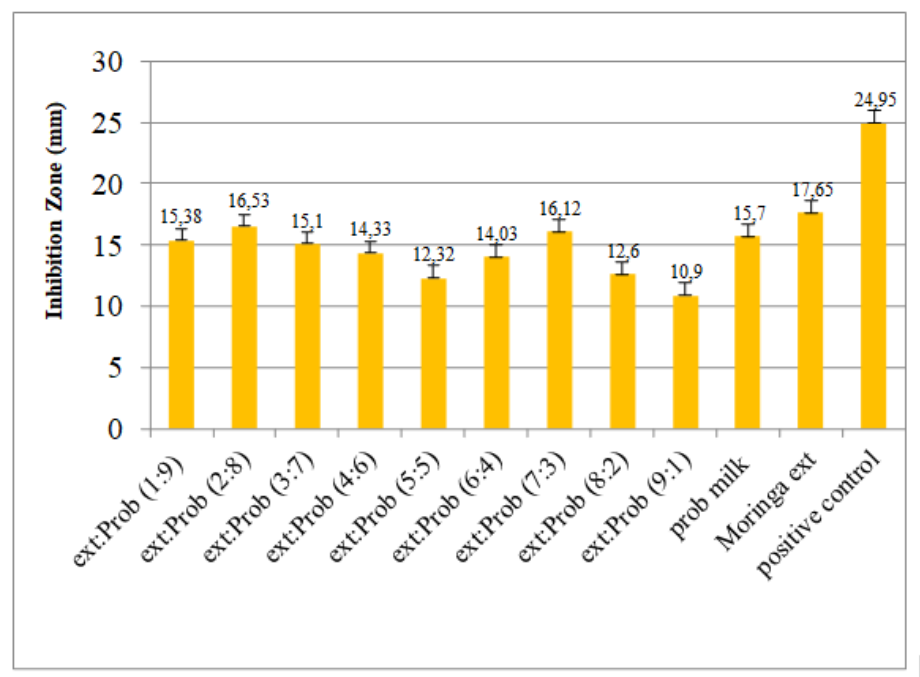

Figure 3. Antibacterial activity of aqueous extract and probiotic fermented milk combination in various ratios. *Superscript means statistically different.

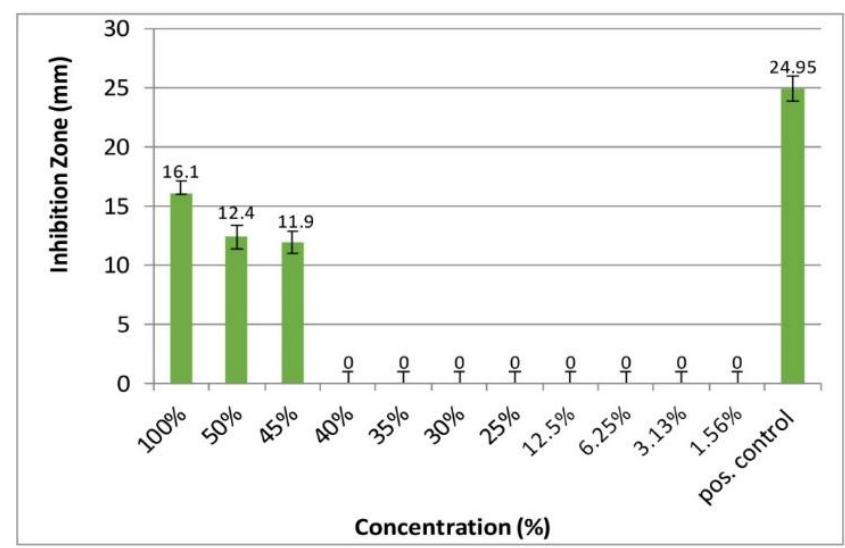

Figure 4. Antibacterial activity of aqueous extract and probiotic fermented milk combination at 8:2. 
The MIC of the Lactobacillus plantarum fermented milk combined with Moringa oleifera leaves aqueous extract $(2: 8)$ indicated that the combination concentration at selected ratio still inhibit Streptococcus mutans growth at $45 \%$ with growth inhibition zone diameter of $11.90 \pm 0.86 \mathrm{~mm}$ (Figure 4 ).

\subsection{Statistical analysis}

The ANOVA method of statistical analysis was performed for assessment of variance among group means (between group variance) compared to the average variance within groups.

Table 5. Tukey' HSD Test results of diameter of Inhibitory zones (mean, three replications) against Streptococcus mutans local strain.

\begin{tabular}{|c|c|c|c|c|c|c|c|c|c|c|c|}
\hline Group & $\begin{array}{l}\text { E:P } \\
1: 9\end{array}$ & $\begin{array}{l}\text { E:P } \\
2: 8\end{array}$ & $\begin{array}{l}\text { E:P } \\
3: 7\end{array}$ & $\begin{array}{l}\text { E:P } \\
4: 6\end{array}$ & $\begin{array}{l}\text { E:P } \\
5: 5\end{array}$ & $\begin{array}{l}\text { E:P } \\
6: 4\end{array}$ & $\begin{array}{l}\text { E:P } \\
7: 3\end{array}$ & $\begin{array}{l}\text { E:P } \\
8: 2\end{array}$ & $\begin{array}{l}\text { E:P } \\
9: 1\end{array}$ & $\mathbf{P}$ & E \\
\hline E:P & & 0.627 & 1.000 & 0.738 & 0.000 & 0.404 & 0.965 & 0.002 & 0.000 & 1.000 & 0.015 \\
\hline $1: 9$ & & & & & & & & & & & \\
\hline $\begin{array}{l}\text { E:P } \\
2: 8\end{array}$ & 0.627 & & 0.323 & 0.020 & 0.000 & 0.006 & 1.000 & 0.000 & 0.000 & 0.920 & 0.665 \\
\hline $\begin{array}{l}\text { E:P } \\
3: 7\end{array}$ & 1.000 & 0.323 & & 0.952 & 0.002 & 0.720 & 0.773 & 0.006 & 0.000 & 0.992 & 0.004 \\
\hline $\begin{array}{l}\text { E:P } \\
4: 6\end{array}$ & 0.738 & 0.020 & 0.952 & & 0.042 & 1.000 & 0.103 & 0.123 & 0.000 & 0.387 & 0.000 \\
\hline $\begin{array}{l}\text { E:P } \\
5: 5\end{array}$ & 0.000 & 0.000 & 0.002 & 0.042 & & 0.131 & 0.000 & 1.000 & 0.338 & 0.000 & 0.000 \\
\hline $\begin{array}{l}E: P \\
6: 4\end{array}$ & 0.404 & 0.006 & 0.720 & 1.000 & 0.131 & & 0.032 & 0.323 & 0.000 & 0.156 & 0.000 \\
\hline $\begin{array}{l}\text { E:P } \\
7: 3\end{array}$ & 0.965 & 1.000 & 0.773 & 0.103 & 0.000 & 0.032 & & 0.000 & 0.000 & 1.000 & 0.240 \\
\hline $\begin{array}{l}\text { E:P } \\
8: 2\end{array}$ & 0.002 & 0.000 & 0.006 & 0.123 & 1.000 & 0.323 & 0.000 & & 0.139 & 0.000 & 0.000 \\
\hline $\begin{array}{l}\text { E:P } \\
\text { 9:1 }\end{array}$ & 0.000 & 0.000 & 0.000 & 0.000 & 0.338 & 0.000 & 0.000 & 0.139 & & 0.000 & 0.000 \\
\hline $\mathrm{P}$ & 1.000 & 0.920 & 0.992 & 0.387 & 0.000 & 0.156 & 1.000 & 0.000 & 0.000 & & 0.055 \\
\hline E & 0.015 & 0.665 & 0.004 & 0.000 & 0.000 & 0.000 & 0.240 & 0.000 & 0.000 & 0.055 & \\
\hline
\end{tabular}

P: Fermented milk

E: Extract

* Superscript means statistically different

: significant different value $(\mathrm{p}<0.05)$

Regarding the inhibitory activities against Streptococcus mutans the samples have been compared included aqueous extract of Moringa oleifera, fermented milk and their combinations at all proportions. Alpha (a) level 0.05 was set for each comparison. An unacceptably increased total error rate of $p$ 95\% might be expected for the total comparisons procedure in the experiment. Furthermore, Tukey' HSD was used for multiple comparisons procedure with diameter of inhibitory zone as dependent variable (Table 5). 


\subsection{Characterization of the fermented milk}

The Lactobacillus plantarum fermented milk had total number of probiotic colony of $1.78 \times 10^{11} \pm 2.59 \times$ $10^{11} \mathrm{CFU} / \mathrm{mL}$ calculated by Total Plate Count (TPC) using MRS media after 24 hours incubation (Table 3). This result is suitable to SNI (Indonesia National Standard) for yogurt or probiotic fermented milk requirement $\left(\geq 10^{7} \mathrm{CFU} / \mathrm{mL}\right)$.

\subsection{Characterization of combination of the fermented milk and aqueous extract}

Characterization (physical performance, color, odor, taste, $\mathrm{pH}$, specific gravity and viscosity value) of the Lactobacillus plantarum ATCC 8014 fermented milk and Moringa oleifera leaves aqueous extract at 2:8 composition was done to ensure reproducibility results if done under the same conditions. Their characterization included $\mathrm{pH}$ value of $4.00 \pm 0.00$, specific gravity value of $1.03 \pm 0.00 \mathrm{~g} / \mathrm{mL}$ and viscosity value of $140.04 \pm 0.00 \mathrm{dPas}$ (Table 4).

\subsection{Determination of MIC}

Determination of growth inhibitory activity of the Moringa oleifera leaves aqueous extract against Streptococcus mutans growth was performed at various concentrations. The MIC profile of the Moringa oleifera leaves aqueous extract showed that the extract at $20 \%$ still inhibit Streptococcus mutans with growth inhibition zone diameter of $11.70 \pm 0.28 \mathrm{~mm}$ (Figure 1).

The MIC determination of L. plantarum probiotic milk against Streptococcus mutans was done at various concentrations. The results showed that Lactobacillus plantarum fermentation milk at $35 \%$ still inhibited the Streptococcus mutans growth with inhibitory zone diameter of $12.02 \pm 0.83 \mathrm{~mm}$ (Figure 2). Determination of antibacterial activity of the fermented milk combined with Moringa oleifera leaves aqueous extract at various ratios was investigated from the largest zone diameter. The results showed that composition of the fermented milk and the aqueous extract with the largest growth inhibitory zone diameter was 2:8 with value of $16.53 \pm$ $0.32 \mathrm{~mm}$ (Figure 3).

The MIC of the Lactobacillus plantarum fermented milk combined with Moringa oleifera leaves aqueous extract $(2: 8)$ indicated that the combination concentration at selected ratio still inhibit Streptococcus mutans growth at $45 \%$ with growth inhibition zone diameter of $11.90 \pm 0.86 \mathrm{~mm}$ (Figure 4).

\subsection{Statistical analysis}

The ANOVA method of statistical analysis was performed for assessment of variance among group means (between group variance) compared to the average variance within groups. Regarding the inhibitory activities against Streptococcus mutans the samples have been compared included aqueous extract of Moringa oleifera, fermented milk and their combinations at all proportions. Alpha (a) level 0.05 was set for each comparison, an unacceptably increased total error rate of $\mathrm{p} 95 \%$ might be expected for the total comparison procedure in the experiment. Furthermore, Tukey' HSD was used for multiple comparisons procedure with diameter of inhibitory zone as dependent variable.

\section{DISCUSSION}

Antibacterial activity of the aqueous extract of Moringa oleifera leaves, Lactobacillus plantarum ATCC 8014 probiotic milk and their combination against Streptococcus mutans was done using agar diffusion method. The advantages of this method are cheap, effective and sensitive. Sensitivity of the bacterial test in the method is the important role to produce good correlation between antibiotic or the test sample concentration and their inhibitory activities. The positive control used in this study was clindamycin (0.01 ppm), a highly effective antibacterial agent for healing tooth decay due to the growth of Streptococci bacteria [10] with MIC of 0.05-0.25 ppm [11]. In the case of a tooth abscess; that is usually caused by infection by streptococci and secondary effects of caries [12].

The MIC determination of Moringa oleifera leaves aqueous extract by serial dilution of $100 \%, 50 \%, 25 \%$, $12.5 \%, 6.25 \%, 3.125 \%, 1.563 \%$ sample solution indicated that growth inhibition zone appeared at $25 \%$ to $100 \%$ concentration and there were no activities produced at the concentrations below 25\%. The repeated testing using $12.5 \%$ to $25 \%$ samples solution were done to obtain the smallest concentration that can still inhibit the test bacterial growth. Growth zone inhibitory was exhibited by equal or more than $20 \%$ sample concentration. Previous studies revealed that ethanol and aqueous extract of the Moringa oleifera leaves showed effective activities against Gram positive bacteria [13], whereas no reports on the aqueous extract activities against 
Streptococcus mutans. It was suggested that Moringa oleifera leaves extract might be useful in the control of many infectious disease alone or together with other antibacterial agents.

One of the aims of this study was to assess the inhibitory effect of Lactobacillus plantarum fermented milk denoted as its MIC. Serial dilution was made by concentrations of $100 \%, 50 \%, 25 \%, 12.5 \%, 6.25 \%, 3.125 \%$, and $1.563 \%$. It was found that no activity seen at concentrations of lower than $50 \%$. Moreover, the MIC evaluation was performed in $25 \%$ to $50 \%$. The smallest concentration that can still inhibit the bacteria test was $35 \%$. The antibacterial activities of probiotic fermented milks are mainly connected with cell viability $\left(10^{11} \mathrm{cFu} / \mathrm{mL}\right)$ and might be caused by their ability to produce different antimicrobial compounds such as organic acids, hydrogen peroxide, and antimicrobial ruterin, peptide such as bacteriocins [14]-[15]. The pasteurized milk acts as nutritional source for the probiotic cell, lead to the metabolic processes taken place completely. Isolation of 19 strains of Lactobacillus plantarum from cheeses derived from unpasteurized milk and assessed their antimicrobial activities. It has been found that the activity level was different depending on the Lactobacillus plantarum strain and connected with the source from which a given strain was isolated [4].

It was found that inhibitory activity of combination of $50 \%$ aqueous extract and Lactobacillus plantarum ATCC 8014 fermented milk (2: 8, v/v) against Streptococcus mutans showed significant differences with other comparison groups $(4: 6,5: 5,6: 4,8: 2$, and 9:1, v/v). The comparison group $(4: 6,5: 5,6: 4,8: 2,9: 1, \mathrm{v} / \mathrm{v})$ obtained a smaller diameter of growth inhibitory zone (Figure 3$)$. The combination $(2: 8, \mathrm{v} / \mathrm{v})$ influenced the increase in inhibitory activity on the growth of the increase in inhibition zone diameter significantly. So that the selected comparison was a combination of $50 \%$ aqueous extract of Moringa oleifera with Lactobacillus plantarum ATCC 8014 fermented milk (2:8, v/v). The combination of this optimal ratio showed a lower inhibition zone diameter value than the inhibitory zone diameter value of $50 \%$ aqueous extract of Moringa oleifera without addition of the fermented milk, but this difference was not significant based on the one-way ANOVA statistical test. While when compared with the value of the inhibitory zone diameter produced by the fermented milk without addition of the extracts, the value of the diameter of the inhibitory zone in the selected ratio was still greater, but the value of the difference was also not significant.

The main purpose of this research was to achieve synergistic and unique antibacterial activities by combining the Moringa oleifera aqueous extract and the Lactobacillus plantarum fermented milk, due to the different active compounds in each preparation component. Base on the preliminary study, addition of the Moringa oleifera leaves aqueous extract might affect cell viability and antibacterial activity of the probiotic fermented milk, because of the antibacterial containing compounds in the extract. Optimization of antibacterial activity of the combination fermented milk and extract was carried out in various compositions of $1: 9,2: 8,3: 7,4: 6,5: 5,6: 4,7: 3,8: 2,9: 1$. The antibacterial activities were exhibited by all composition and the strong activity represented by 2:8 composition of Lactobacillus plantarum ATCC 8014 fermented milk and 50\% Moringa oleifera leaves aqueous extract with growth inhibition zone diameter of $16.53 \pm 0.32 \mathrm{~mm}$. Based on previous studies, Moringa oleifera leaves contained various compounds such as phenolic, tannin, saponin, flavonoid, terpenoid, alkaloid, anthraquinone, and carbohydrates. The total phenolic content in the Moringa oleifera leaves was $2.28 \pm 0.22 \mathrm{mg} / \mathrm{mL}$ [16]. Carbohydrates content in the Moringa oleifera leaves might be a nutrient forming of lactic acid in fermented milk [17], and synergistic relationship between fermented milk of Lactobacillus plantarum and phenolic content in the Moringa oleifera leaf at ratio of 2:8 in those combination, might increase antibacterial activity [18] compared to single fermented milk and other composition of the combinations. The selected ratio of fermented milk of Lactobacillus plantarum ATCC 8014 and 50\% Moringa oleifera leaf aqueous extract (2:8) combination was then tested for the MIC. Using the same procedure as MIC test in each sample, MIC of the selected combination against Streptococcus mutans was $45 \%$ with growth inhibition zone diameter of $11.90 \pm 0.86 \mathrm{~mm}$. This MIC value was higher than both MIC of the $100 \%$ aqueous extract $(20 \%)$ and fermented milk (35\%). The Moringa oleifera aqueous extract represented potent antibacterial activity either alone or together with the Lactobacillus plantarum fermented milk. However, the combination is expected to contribute the diversity mechanisms as antibacterial activities and other useful and additional activities, due to their different active compounds. The combination is also shows a promising future in the food supplement preparation to overcome infectious diseases.

\section{CONCLUSION}

The results of this study showed that both aqueous extract of Moringa oleifera leaves and Lactobacillus plantarum ATCC 8014 fermented milk inhibited local strain of Streptococcus mutans growth with MIC value of $20 \%$ and $35 \%$, respectively. Their combination was active against the test bacterial at all ratios and the strongest growth inhibition indicated at 2:8 ratio of Lactobacillus plantarum ATCC 8014 fermented milk and 
$50 \%$ aqueous extract of Moringa oleifera leaf with MIC value of $45 \%$. Since the extract dominated the activities, further observation in detail interaction between the extract and the probiotic viability is very important. Due to the possibility antibacterial effect of the Moringa oleifera extract against the Lactobacillus plantarum, optimization should be developed to achieve increasing potency of the antibacterial activity. Compatibility test is very useful to ensure that all components of the combination produced synergistic activities. Anyhow, the combination of preparation could be considerate as good candidate for healthy or functional foods or foods supplement, especially to overcome problems of infectious diseases and tooth decay due to the Streptococci bacteria.

\section{MATERIALS AND METHODS}

\subsection{Materials}

Fresh Moringa oleifera leaves were collected from Campus B area of Airlangga University, Surabaya, East Java; which had been determined in The Materia Medica (Botanical Garden), Batu Malang, East Java. Müller Hinton Agar (Oxoid) media, MRS (de Man Ragosa Sharpe) media (Himedia lab), Nutrient agar media, $\mathrm{NaCl}$ pa (E. Merck), Fresh cow milk obtained from the market, and clindamycin Pharmaceutical Grade (PT Novel). The local strain of Streptococcus mutans obtained from the Faculty of Dentistry Airlangga University Surabaya, and Lactobacillus plantarum ATCC 8014.

\subsection{Preparation of aqueous extract of Moringa oleifera leaves}

The $50 \%$ fresh Moringa oleifera leaves was made as infuse. The $50 \mathrm{~g}$ of fresh Moringa oleifera leaves mixed with distilled water, and boiled on a water bath for 5 minutes at $90^{\circ} \mathrm{C}$, and then filtered. The water was added to $100 \mathrm{~mL}$ volume [19]. Sterilization of the extract was carried out with a membrane filter of $0.22 \mathrm{~mm}$ in a laminar air flow cabinet.

\subsection{Preparation of fermented milk}

Preparation of fermented milk was started from Lactobacillus plantarum ATCC 8014 starter preparation. Three Öse cultures of fresh Lactobacillus plantarum ATCC 8014 on slant MRS agar medium were inoculated into $10.0 \mathrm{~mL}$ pasteurized milk (heated at $90^{\circ} \mathrm{C}$ for 15 minutes) at $43^{\circ} \mathrm{C}$. The mixture was incubated for 24 hours at $37^{\circ} \mathrm{C}$ [20]. Development of fermented milk was done by adding a starter $(5.0 \mathrm{~mL})$ into $100.0 \mathrm{~mL}$ pasteurized milk and mixed at $43^{\circ} \mathrm{C}$. The mixture was allowed for 24 hours at $37^{\circ} \mathrm{C}$. Development of fermented milk was repeated by adding a starter $(50.0 \mathrm{~mL})$ to one liter of pasteurized milk and mixed at $43^{\circ} \mathrm{C}$. The mixture was allowed for 24 hours at $37^{\circ} \mathrm{C}$.

\subsection{Preparation of aqueous extract of Moringa oleifera leaves and probiotic fermented milk combination}

The $50 \%$ of aqueous extract and probiotic fermented milk were used as original solution. Combinations were made with various ratios; ie 1:9 (10\% fermented milk $+90 \%$ aqueous extract), $2: 8$ (20\% fermented milk + $80 \%$ aqueous extract), 3:7 (30\% fermented milk $+70 \%$ aqueous extract), $4: 6$ (40\% fermented milk $+60 \%$ aqueous extract), 5:5 (50\% fermented milk $+50 \%$ aqueous extract), $6: 4$ (60\% fermented milk $+40 \%$ aqueous extract), $7: 3$ (70\% fermented milk $+30 \%$ aqueous extract), $8: 2$ (80\% fermented milk $+20 \%$ aqueous extract) and 9:1 (90\% fermented milk $+10 \%$ aqueous extract) [6].

\subsection{Preparation of test media}

The Müller Hinton agar was used as the test medium and prepared in two tubes containing 12.0 and 8.0 $\mathrm{mL}$ of base layer and seed layer media, respectively. The seed layer media was added by $5 \mu 1$ of test bacterial suspension (Streptococcus mutans with transmitant of $25 \%$ at $\lambda 580 \mathrm{~nm}$ ) at $45-50^{\circ} \mathrm{C}$ and homogenized using vortex, and then poured on top of solidified base layer surface. The two layers media were perforated with sterile stainless boor to gain hole (wells) with 0.5 and $0.8 \mathrm{~cm}$, respectively [21].

\subsection{Phytochemistry analysis of aqueous extract of Moringa oleifera leaves}

Characterization of the Moringa oleifera leaves aqueous extract was done by analyzing quality and phytochemical contents. Quality analyzes included organoleptic, color, odor, taste, $\mathrm{pH}$ and specific gravity values. Their phytochemical contents (saponin glycoside, tanin, glycoside, alkaloid, terpenoid, flavonoid) analysis was done based on Vinoth et al. [8]. 


\subsection{Characterization of fermented milk}

Characterization of Lactobacillus plantarum ATCC 8014 fermented milk was performed by qualitative analysis including physical performance, color, odor, taste, $\mathrm{pH}$ value, density value using lacto-densitometer, and viscosity value using cup and bob viscometer. The observation results were compared to standard requirement [22].

\subsection{Characterization of aqueous extract and fermented milk combination}

The characterization of combination between the Moringa oleifera aqueous extract and fermented milk in the selected ratio was performed with quality analysis including physical performance, color, odor, taste, $\mathrm{pH}$, density and viscosity value.

\subsection{Growth inhibitory activity test}

Optimization of growth inhibitory activity of the fermented milk and extract combination was carried out in various compositions of 1:9, 2:8, 3:7, 4:6, 5:5, 6:4, 7:3, 8:2, and 9:1. Each test solution (fermented milk, extract and its combinations) was loaded into hole reservoir on the test medium, incubated at $37^{\circ} \mathrm{C}$ for 24 hours, inhibitory zone diameter was observed and measured using digital caliper $(\mathrm{mm})$. Then the selected ratio resulting in the highest activity was determined based on the inhibitory zone diameter value. The MIC of each test solution including the optimum ratio of fermented milk and extract combination was performed by serial dilution of $100 \%, 50 \%, 25 \%, 12.5 \%, 6.25 \%, 3.125 \%$ and $1.563 \%$ concentrations. Thereafter, each test solution was assayed according to the method above.

Acknowledgements: This research was supported by research grant from Faculty of Pharmacy, Airlangga University in 2017.

Author contributions: Concept - I., I. K., A.M., E.M.S.; Design - I., I. K., A.M., E.M.S..; Supervision - I., I.K.; Resource - I., A.M.; Materials - I., A.M., E.M.S; Data Collection and/or Processing - I., A.M., I. K.; Analysis and/or Interpretation - I., A.M., I.K, E.M.S.; Literature Search - I., I. K., A.M.; Writing - I., I. K., A.M., E.M.S.; Critical Reviews - I., I. K., A.M., E.M.S.

Conflict of interest statement: The authors declared no conflict of interest in the manuscript.

\section{REFERENCES}

[1] Amiruddin SH. Master Thesis. Daya hambat ekstrak bawang putih (Allium sativum) terhadap pertumbuhan Streptococcus mutans galur lokal secara in vitro, Universitas Hasanudin, Makasar, Indonesia, 2014.

[2] Selwitz, Robert H, Amid I, Nigel BP. Dental Caries, Vol. 369, Department of Community Dentistry and Behavioral Science, University of Florida, 2007.

[3] Chang MH, Hong SF, Chen JH, Lin MF, Chen. CS, Wang, SC. Antibacterial activity Lactobacillus plantarum isolated from fermented vegetables and investigation of the plantaricin genes. Afr J Microbiol Res. 2016; 10(22): 796-803.

[4] Oldak A, Dorota Z, Anna R, Danuta K. Comparison of antibacterial activity of Lactobacillus plantarum strains isolated from two different kinds of regional cheeses from Poland: Oscypek and Korycinski Cheese. Bio Med Res. Int. 2017; 2017: 1-10.

[5] WHO. Oral health information systems. 2014. http://www.who.int/oral_health/action/information/surveillance/en/ (accessed on 02 December, 2016).

[6] Istiqomah I. Thesis. Aktivitas antibakteri kombinasi susu probiotik Lactobacilli dan ekstrak air daun jambu biji (Psidium guajava) terhadap bakteri penyebab diare. Faculty of Pharmacy, Airlangga University, Surabaya, Indonesia, 2014.

[7] Gopalakrishnan L, Kruthi D, Devarai SK. Moringa oleifera: A review on nutritive importance and its medicinal application. Food Sci Human Wellness. 2016; 5: 49-56. [CrossRef]

[8] Vinoth B, Manivasagaperumal R, Balamurugan S. Phytochemical analysis and antibacterial activity of Moringa oleifera. Int J Res Biol Sci. 2012; 2(3): 98-102.

[9] Sumarni W, Sudarwati D. Uji aktivitas senyawa antibakteri pada ekstrak daun kelor dan bunga rosella. Ind J Chem Sci. 2016; 5: 11-14. 
[10] Katzung GB, Masters BS, Trevor JA. Basic and Clinical Pharmacology, twelfth Edition, The United States McGrawHill Companies Inc. USA, 2012.

[11] Liebana J, Castillo A, Peis J, Baca P, Piedrola G. Antimicrobial susceptibility of 1024 strains of Streptococcus mutans and Streptococcus sobrinus: Comparison from 1985 to 1989. Oral Microbiol Immunol. 1991; 2991(6): 146-150. [CrossRef]

[12] Shweta, Prakash SK. Dental abscess: Microbiologycal review. Dent Res J (Isfahan). 2013; 10(5): 585-591.

[13] Zaffer M, Ahmad S, Sharma R, Mahajan S, Gupta A, Agnihotri RK. Antibacterial activity of bark extracts of Moringa oleifera Lam. against some selected bacteria. Pak J Pharm Sci. 2014; 27(6): 1857-1862.

[14] Cortés-Zavaleta O, López-Malo A, Hernández-Mendoza A, García HS. Antifungal activity of lactobacilli and its relationship with 3-phenyllactic acid production. Int J Food Microbiol. 2014; 173: 30-35. [CrossRef]

[15] Jason MN, Xiaonan L, Tri D, Charles LL, Douglas RC, Devendra HS, Michael EK. Production of organic acids by probiotic Lactobacilli can be used to reduce pathogen load in poultry. PLoS One 2012; 7(9): e43928. [CrossRef]

[16] Vernekar, Vrunda, Sankhalkar S. Quantitative and qualitative analysis of phenolic and flavonoid content in Moringa oleifera Lam and Ocimum tenuiflorum L. Pharm Res. 2016; 8: 16-21. [CrossRef]

[17] Campos A, Perez, Mena, AL. Lactobacillus classification, uses, and health implication, Nova biomedical, Nova Science Publisher, Inc., New York 2012.

[18] Peres CM, Mendonza H, Bronze MR, Peres C, Malcata F. Synergy of olive bioactive phytochemicals and probiotic strain in control Escherichia coli. LWT-Food Sci Tech. 2015; 64(2): 938-945. [CrossRef]

[19] DepKes, RI. Parameter standar umum ekstrak tumbuhan obat. Departemen Kesehatan Republik Indonesia, Direktorat Pengawasan Obat dan Makanan, Direktorat Pengawasan Obat Tradisional , Indonesia 2000.

[20] Isnaeni, Mertaniasih NM. Antibacterial activity of probiotic mixed culture against MRSA and ESBL. J Chem Pharm Res. 2015; 7(4): 1005-1010.

[21] DepKes, R., I. Farmakope Indonesia Edisi V, Departemen Kesehatan Republik Indonesia, Jakarta, Indonesia. 2014.

[22] SNI, Standar Nasional Indonesia, Batas Maksimum Cemaran Mikroba dalam Pangan, Badan Standardisasi Nasional, Jakarta, Indonesia. 2009 